\title{
The Role of EFL Teachers' Self-regulation in Effective Teaching
}

\author{
Mohammad Taghi Monshi Toussi \\ Department of English Language, Islamic Azad University \\ Mashhad Branch, Iran \\ E-mail: m_toussi2002@yahoo.com
}

Ali Akbar Boori

Department of English Language, Islamic Azad University

Mashhad Branch, Iran

E-mail: boori@mshdiau.ac.ir

Afsaneh Ghanizadeh (Corresponding author)

Department of English Language, Islamic Azad University

Mashhad Branch, Iran

Tel: 98-915-304-8141_Ｅ-mail: ghanizadehafsaneh@yahoo.com

$\begin{array}{lll}\text { Received: June 3, } 2011 & \text { Accepted: July 15, } 2011 & \text { Published: October 1, } 2011 \\ \text { doi:10.5430/wje.vln2p39 } & \text { URL: http://dx.doi.org/10.5430/wje.vln2p39 }\end{array}$

\begin{abstract}
This article investigated the relationship between EFL teachers' self-regulation and teaching effectiveness. In so doing, 76 EFL teachers were selected according to a convenience sampling from different English language institutes in Mashhad, a city in north-eastern Iran. The findings of the study indicated that there is a significant relationship between EFL teachers' self-regulation and their teaching effectiveness. Subsequent data analyses indicated that among the components of self-regulation, intrinsic interest, mastery-goal orientation, and emotional control have the highest correlations with teaching effectiveness. Based on the findings of the present study teacher educators, administrators, and policy makers are recommended to incorporate self-regulated learning strategies to teacher training programs. The findings of the present study may also highlight the contributing roles of intrinsic and emotional factors in teaching effectiveness.
\end{abstract}

Keywords: EFL teachers, Emotional control, Intrinsic interest, Mastery-goal orientation, Self-regulation, Teaching effectiveness

\section{Introduction}

The literature related to effective teaching reveals that there are a multitude of definitions for what constitutes effective teaching. Indeed, conceptualization of teaching effectiveness has been under the influence of the existing psychological and educational models and theories. For example, in the era of behaviorism, teaching effectiveness was evaluated in the light of teachers' pre-defined behaviors and students' achievements. Under the influence of cognitivism, effective teachers were evaluated based on the process of teaching and learning rather than the prescribed and observable product. The period from 1980 to $21^{\text {st }}$ century, studies in the field of education underwent a reform movement which influenced all aspects of education including teacher effectiveness and the characteristic features of successful teachers (Ellett \& Teddlie, 2003). As the result, various affective, cognitive and social characteristics were incorporated to the definitions and measures of effective teaching. A substantial theoretical and empirical base now exists in the literature that demonstrates the association of each of these constructs with the teachers' pedagogical success. In EFL contexts, for instance, emotional intelligence (Ghanizadeh \& Moafian, 2010) and self-efficacy (Ghanizadeh \& Moafian, 2011) have been found to be influential factors in teaching effectiveness. In a similar vein, Bagherkazemi and Birjandi (2010) reported a positive relationship between EFL teachers' critical thinking ability and their professional success. Despite the growing interest in investigating the influential role of teachers' functional, cognitive and affective skills, there are hardly any documented studies investigating the relationship between EFL teachers' success and their metacognitive 
abilities, particularly self-regulation.

Self-regulation refers to self-initiated actions, thoughts and feelings that involve regulating one's efforts to reach the goal (Zimmerman \& Risemberg, 1997). In the realm of education, self-regulatory skills have been found to be associated with students' achievement and motivation (Zimmerman \& Schunk, 2001). The trends observed with respect to the role of student self-regulation in their academic success also generalize to teachers. As Cardelle-Elawar, Irwin and Lizarraga (2007) maintained successful teachers are self-regulated individuals who understand themselves as teachers and sustain their motivation encountering different tasks, diverse students and changing circumstances. Furthermore, self-regulation can help teachers gain a better understanding of their students' needs and learning experiences, have a deeper sense of the teaching and learning strategies, and emulate for the students (Paris \& Winograd, 2001).

Although the above mentioned studies highlight the contributing effect of self-regulation on teachers' practices and instructional behaviors, there is a scarcity of such research on EFL teachers' pedagogical behaviors and achievements. The dearth of investigation into the possible role played by teachers' self-regulation in their professional and educational effectiveness in EFL contexts echoes a clear need to undertake identical studies in this area.

\section{Literature Review}

\subsection{Review of literature on effective teaching}

As indicated earlier, teaching effectiveness is not a unitary concept; rather, it is a multifaceted notion encompassing many dimensions and attributes. For instance, Kyriakides, Campbell, and Christofidou (2002) summarized related literature on effective teaching and pointed out that effective teachers can provide adequate quantity of instruction, organize and manage the classroom environment, effectively use instructional time, structure instructional materials, give students practice and application opportunities, provide good classroom climate, and have enough subject knowledge. Teaching effectiveness has also been associated with meeting course objectives and creating and sustaining situations conducive to learning (Weeler \& Mcleod, 2002). Gadzella (1977) conceptualized an ideal teacher as the one who is knowledgeable in subject matter, interested in subject matter, and flexible in presenting materials. In a similar vein, Hiebert, Morris, Berk and Jansen (2007) associated the following skills with successful teachers: 1) specifying learning goals for students; 2) evaluating if the goals being reached; 3) hypothesizing the effects of teaching on students' learning and 4) analyzing to improve teaching and learning quality.

In the present study teachers' success is evaluated according to the criteria adopted in the "Characteristics of Successful Iranian EFL Teachers Questionnaire". As the name suggests this student-evaluated questionnaire is specific to EFL teachers and is consistent with the Iranian context.

\subsection{Review of literature on self-regulation}

Self-regulation is defined as the "process of setting goals for oneself and engaging in behaviors and cognitive processes that lead to goal completion" (Bandura, 1986, p. 347). Zimmerman (2000) viewed self-regulation as the degree to which learners are motivationally, metacognitively, and behaviorally active in their learning process and in achieving their goals. According to Zimmerman (1990) during the metacognitive phase, individuals set goals, impose structure on the learned materials, and self-assess their performance. Via the motivational processes, individuals exhibit persistence, high self-efficacy perceptions, and intrinsic task interest. The behavioral processes enable them to select, organize and control the performed task. They are also involved in self-instructing and self-reaction during task performance.

Theories and practices associated with self-regulation have been extensively applied to educational settings and school learning, leading to the development of self-regulated learning theory. Self-regulated learning encompasses three main components- cognition, metacognition, and motivation- which can be further subdivided into several subcomponents (Schraw, Crippen \& Hartley, 2006). Cognitive component includes simple strategies, problem solving, and critical thinking. Metacognitive component consists of two general components- knowledge of cognition and regulation of cognition- each includes several subcomponents as: declarative, procedural, conditional knowledge and planning, monitoring, evaluation, respectively. Finally, the motivation component comprises two subcomponents: self-efficacy and epistemological beliefs.

According to Zimmerman (1990), self-regulated learners possess several attributes as follows:

Self-regulated learners are aware when they know a fact or possess a skill and when they do not. Unlike heir passive classmates, self-regulated students proactively seek out information when needed and take the necessary steps to master it. When they encounter obstacles such as poor study conditions, confusing teachers, or abstruse textbooks, they find a way to succeed. Self-regulated learners view acquisition as a systematic and controlled process, and they accept greater responsibility for their achievement outcomes. (p. 4) 
Empirical studies demonstrated that self-regulation is positively correlated to academic achievement and other cognitive and affective factors conducive to learning. For instance, Zimmerman and Martinez-Pons (1986) maintained that self-regulated learning strategies like rehearsal, elaboration, reflection, and goal settings are decisive factors in students' successful performance. Similarly, Zimmerman (1990) revealed that the level of selfregulation predicted the academic track of the students. Pintrich and De Groot (1990) found a dynamic interplay between motivational beliefs and self-regulated learning. Kitsantas (2000)'s study substantiated a positive relationship between self-efficacy and metacognitive strategy use which produced successful performance outcomes (cited in Hoffman \& Spatariu, 2008).

Since research has indicated students' use of self-regulatory behaviors to be critical for academic achievement, it is plausible that the teachers' use of self-regulatory behaviors would positively influence teacher practices. Baylor, Kitsantas and Chung (2001) stated that teacher self regulatory strategies can guide students' learning during self-directed practice and promote their skills in developing effective lesson plans. In L2 context, situating self-regulation within the framework of reflective teaching, Ghanizadeh (2011) indicated that self-regulation and critical thinking ability are positively correlated. It has been also found that teacher self-regulation has a contributing role in promoting EFL teachers' sense of self-efficacy (Ghonsooli \& Ghanizadeh, forthc.). Viewing from another perspective, it seems plausible to presume teachers who lack self-regulatory skills will find it difficult to scaffold activities and experiences which enhance their students' self-regulatory strategies.

Upon what was noted about the influential role of teachers' self-regulation in their pedagogical behaviors, investigating the relationship between teachers' self-regulation and their professional success, and the question of how much teachers' self-regulation contributes to the prediction of their success becomes a paramount inquiry for EFL researchers. In summary, the present study seeks to investigate such a relationship among EFL teachers and in Language Institutes. To this end, the following research questions were posed and investigated in this study:

1) Is there any significant relationship between EFL teachers' self-regulation and their pedagogical success?

2) Among the components of teaches' self-regulation which one(s) has/have the highest correlation(s) with their pedagogical success?

3) Among the components of teaches' self-regulation which one(s) is/are the positive predictor(s) of their pedagogical success?

\section{Method}

\subsection{Participants}

A sample of convenience was used for this study. The population sample consisted of Iranian EFL teachers who were teaching English in 6 private institutes in Mashhad, a city in the north-east of Iran between July and October 2010. There were no requirements other than that the participants be currently teaching an English course during the summer semester of 2010. The target number of teachers for the study was 90 , out of which 76 teachers agreed to participate. There were 48 females and 28 males; their age varied from 21 to 42 years old $(\mathrm{M}=26.31, \mathrm{SD}=4.05)$ and their teaching experience varied from 1 to 19 years $(\mathrm{M}=4.16, \mathrm{SD}=3.86)$. They mostly majored in the different branches of English English Literature (12 B.A, 2 M.A), English Teaching (25 B.A, 15 M.A), English Translation (7 B.A).

The second group of participants comprised 724 EFL learners (students of the above-mentioned teachers). They were 532 females and 192 males whose age varied from 15 to $48(\mathrm{M}=21.45, \mathrm{SD}=4.12)$. Their language proficiency varied from elementary to advanced level and their educational level varied from high school to BA/S.

\subsection{Instruments}

\subsection{Teacher Self-Regulation Scale (TSRS)}

To assess teacher self-regulation, the researchers utilized the 'Teacher Self-Regulation Scale (TSRS)', designed and validated by Yesim, Sungur \& Uzuntiryaki (2009). It was developed based on Zimmerman's self -regulation model and semi-structured interviews with pre-service and in-service teachers; and consists of 40 items on a 6 point Likert scale ranging from 'strongly disagree' to 'strongly agree'. One item was also included as a filler item which was not used in further analyses. Confirmatory factor analysis yielded the following nine factors.

$<$ Table 1 about here $>$

Scores on the 40 items were averaged to form an overall indicator of the teachers' self-regulation, defined by Yesim, Sungur \& Uzuntiryaki (2009) "as teachers' own self-regulated strategies, which they use during lessons" (p. 354). In this study, the total reliability of the scale, estimated via Cronbach's alpha, was 0.89 . 


\subsubsection{Characteristics of Successful Iranian EFL Teachers Questionnaire}

To evaluate language teachers' performance and success in language teaching, the researchers employed the 'Characteristics of Successful Iranian EFL Teachers Questionnaire' (CSIET) (Moafian \& Pishghadam, 2009). It is a Likert scale consisting of 47 items and measuring twelve constructs as Teaching accountability, Interpersonal relationships, Attention to all, Examination, Commitment, Learning boosters, Creating a sense of competence, Teaching boosters, Physical and emotional acceptance, Empathy, Class attendance, Dynamism. In this study, the total reliability of the questionnaire, estimated via Cronbach' alpha, was 0.82 .

\subsection{Data collection}

The study was conducted in 6 private Language Institutes (ILI, Marefat, College, Jahad-edaneshgahi, Kish, and Kish Air) in Mashhad, a city in North-east of Iran, between July and October 2010. The Institutes were selected based on convenience sampling. The teachers were distributed TSRS questionnaire which they completed and delivered back to the researchers. Simultaneously, the CSIET questionnaire was given to the learners of those teachers. Through this questionnaire, the teachers' performance was evaluated by their students. To receive the reliable evaluation by the learners, the researchers explained the purpose of completing the questionnaire and assured the learners that their views would be confidential; besides, both teachers and learners' questionnaires were coded numerically and they were asked not to write any name on their questionnaires. They were just required to provide demographic information such as, gender, age, teaching experience, years of studying English and major.

\section{Results}

Table 2 summarizes the descriptive results of the two instruments- teacher self-regulation (TSRS) and teachers' success (CSIET)- utilized in this study.

$<$ Table 2 about here $>$

To investigate the relationship between teachers' self-regulation and their success, a Pearson product-moment correlation was applied. The results of correlation revealed that there is a significant correlation between EFL teachers' selfregulation and their success $(\mathrm{r}=0.52, \mathrm{p}<0.05)$.

$<$ Table 3 about here $>$

It was also found that there is a positive relationship between EFL teachers' success and the seven subscales of the total self-regulation scores as follow: teacher self-regulation and F2 $(r=0.504, p<.05), F 3(r=0.415, p<.05), F 4(r=0.430$, $\mathrm{p}<.05), \mathrm{F} 6(\mathrm{r}=0.473, \mathrm{p}<.05), \mathrm{F} 7(\mathrm{r}=0.342, \mathrm{p}<.05), \mathrm{F} 8(\mathrm{r}=0.388, \mathrm{p}<.05)$, and F9 $(\mathrm{r}=0.317, \mathrm{p}<.05)$.

$<$ Table 4 about here $>$

To investigate which components of self-regulation might have more predictive power in predicting teachers' success and how other constructs contribute to this model, a regression analysis was employed. The following table is the ANOVA table of regression. The magnitude of F-value and the amount of the respective p-value $(\mathrm{p}<0.05)$ indicate the considered model is significant.

$<$ Table 5 about here $>$

As Table 6 displays, among the nine subscales of self-regulation, intrinsic interest was found to be the positive predictor of the dependent variable (teacher success).

$<$ Table 6 about here $>$

To analyze the data further, regression analysis was conducted. The results indicated that teachers' total score of selfregulation is a positive predictor of the dependent variable (teachers' success).

$<$ Table 7 about here $>$

Table 8 illustrates the model summary statistics. The results revealed that the model containing the total scores of selfregulation can predict 27 percent of the teachers' success. The $\mathrm{R}$ value is 0.52 which indicates the correlation coefficient between teachers' self-regulation and their success. Its square value is 0.26 . It indicates that about $27 \%$ of the variation in teachers' success can be explained by taking their self-regulation into account.

$$
<\text { Table } 8 \text { about here }>
$$

\section{Discussion}

The present study aimed at examining the relationship between Iranian EFL teachers' self-regulation and their pedagogical success in Language Institutes. The results demonstrated that teacher's self-regulation is a significant 
indicator of teacher's success. This is in line with empirical and theoretical contentions highlighting the positive role of teachers' self-regulatory skills in successful accomplishment of their professional tasks. According to Delfino, Dettori, and Persico (2010) the complexity of the individual and social aspects of teaching roles calls for self-regulated teachers who can manifest teaching effectiveness. Indeed, as Randi (2004) maintained from social cognitive perspective, effective teachers are self-regulated agents who can activate their beliefs to take appropriate actions leading to successful and effective teaching. In a similar vein, Dembo (2001) argued that to create opportunities for insightful instruction, teachers not only need content area knowledge, but also have to scrutinize their self-regulatory factors associated with teaching and learning.

The abovementioned studies were all conducted in L1 contexts. The findings of the present study substantiated the positive role of teachers' self-regulation in their pedagogical success among Iranian EFL teachers. In other words, the more EFL teachers equip themselves with the self-regulatory skills, the more likely they will be evaluated successful from the perspective of their students. The context of the present study, i.e., private language institutes in Iran, may have also contributed to this finding. In Iran, most language institutes are characterized by their disciplined conduct and the implementation of communicative language teaching approach (CLT). Being run by private administrations and largely reliant upon language learners' satisfaction, these institutes and specifically teachers in these institutes are under constant evaluation, inspection, and observation by institute authorities, students and their parents. This in turn entails teachers' regular monitoring and regulating of their actions and thoughts. Furthermore, a striking endeavor had been made in Iranian private language institutes to fulfill the students' communicative needs; thus, the executed curriculum is compatible with the principles of CLT. Accordingly, the teachers are expected to serve as facilitators and participants. In other words, what they require is not just content knowledge, but the abilities associated with self-regulation strategies enabling them to plan beforehand and to be motivationally, metacognitively, and behaviorally active in achieving their instructional goals.

As indicated earlier, among the components of self-regulation, intrinsic interest, mastery-goal orientation, and emotional control were found to have the highest correlations with teacher success. The significant correlation to intrinsic interest beliefs concerning personal interest in the profession (Yesim, Sungur \& Uzuntiryaki 2009)- suggests that teachers who are more interested in their work are also more successful. This can be plausibly interpreted from the commonsense perspective, given that individuals who have higher levels of intrinsic interest in their profession are expected to exhibit more persistence, commitment, and effort investment. This in turn would result in the successful accomplishment of their professional tasks. Current research has also confirmed that teachers' high academic sense of intrinsic interest is a useful predictor of their job performance (Bembenutty, 2007).

With the significant correlation between mastery-goal orientation-goals to improve competence in teaching and master the teaching task against self-set standards (Yesim, Sungur \& Uzuntiryaki, 2009)- it would appear that teachers' concern over the mastery of teaching practices tend to enhance their teaching effectiveness. This finding is also consistent with previous studies corroborating a positive relationship between types of goals individuals adopt for learning and their performance. For instance, Dweck \& Leggett (1988) indicated students who adopt a learning or mastery orientation (aiming at developing and improving ability) demonstrate more successful learning behaviors than those who have performance-goal orientation (seeking to demonstrate ability) or performance-avoidance orientation (targeting at hiding lack of ability). In a similar vein, Hsieh, Sullivan and Guerra (2007) found a dynamic interplay between students' adoption of mastery goals and successful college performance.

The significant relationship between emotional control- strategies for controlling and regulating affect, mood, and emotions (Yesim, Sungur \& Uzuntiryaki, 2009)- and teacher success implies that teachers' effective handling of their emotional states tends to foster their teaching effectiveness. This is in line with the bulk of research on successful performance demonstrated that higher level of emotional competencies is an indication of one's potential in academic and professional success (Goleman, 1995; Mayer and Salovey, 1997). In particular, in the domain of teaching effectiveness, Wubbels and Levy (1991) found that teacher emotional intelligence plays an influential role in fostering not only teachers' performance but also learners' cognitive and affective achievements. In L2 contexts identical results have been reported. Ghanizadeh and Moafian's (2009) study revealed that the higher EFL teachers' emotional intelligence, the more successful she/he is from the students' perspectives. The context of the present study- language institutes- may also highlight this finding. The interactive and self-motivated nature of classes in language institutes entail teachers' high emotional competence to encourage and sustain peer and teacher interactions, rapport and motivation.

\section{Conclusions}

Taken together, the major conclusion drawn from the findings of the present study is that developing EFL teachers' self- 
regulatory skills is linked to the enhancement of their success. This in turn should encourage teacher educators, administrators, and policy makers to introduce self-regulated learning strategies to teacher training programs. In line with the current trends in teaching effectiveness, these programs are expected to undergo a shift from curricula pivoting around solid basis of content area knowledge to those equipping teachers with regulating their actions, thoughts and emotions, as recommended by Dembo (2001). Hence, it seems crucial that effective paths for developing self-regulation among teachers are pinpointed.

In line with this, prospective teachers should be equipped with self-regulatory strategies so as to be able to teach these skills and model for their students, since it seems plausible to presume that teachers who lack self-regulatory skills will find it difficult or even impossible to construct the self-regulation of their students.

Furthermore, the contributing effects of intrinsic and emotional factors on teaching, especially those targeted at improving teaching task and personal interest, should be taken into account by the EFL trainers and teachers themselves. Accordingly, teacher educators are recommended to incorporate emotional literacy programs to the agenda of teacher training programs. It is also important to appraise teachers' performance with reference to their prior achievements or their efforts rather than in comparison with other teachers. 


\section{References}

Baylor, A., Kitsantas, A., \& Chung, H. (2001). The Instructional Planning Self-Reflective Tool (IPSRT): A Method for Promoting Effective Lesson Planning. Educational Technology, 41(2), 56-59.

Bembenutty, H. (2007). Teachers' self-efficacy and self-regulation. Academic Exchange Quarterly 2.

Birjandi, P., \& Bagherkazemi, M. (2010). The relationship between Iranian EFL teachers' critical thinking ability and their professional success. English Language Teaching, 3 (2), 135-145.

Braskamp, L.A., Brandenburg, D.C., \& Ory, J.C. (1984). Evaluative teaching effectiveness: A practical guide. Beverly Hills, California: Sage Publication.

Cardelle-Elawar, M., Irwin, L., \& Sanz de Acedo Lizarraga, M.L. (2007). A cross cultural analysis of motivational factors that influence teacher identity. Electronic Journal of Research in Educational Psychology, 5, 565-592.

Crandall, J. (1996). The challenges of professionalism and professionalization in ESL. Keynote address presented at the national TESL Canada Conference. Winnipeg.

Cross, D.R., \& Paris, S.G. (1988). Developmental and instructional analyses of children's metacognition and reading comprehension. Journal of Educational Psychology 80, 131- 142. http://dx.doi.org/10.1037/0022-0663.80.2.131

Delfino, M., Dettori, G., \& Persico, D. (2010). An online course fostering self-regulation of trainee teachers. Psicothema, 22(2), 299-305.

Dembo, M. H. (2001). Learning to teach is not enough — Future teachers also need to learn how to learn. Teacher Education Quarterly, 28, 23-35.

Dweck, C.S., \& Leggett, E.L. (1988). A social-cognitive approach to motivation and personality. Psychological Review, 95, 256-273. http://dx.doi.org/10.1037/0033-295X.95.2.256

Ellett, C.D., \& Teddlie, C. (2003). Teacher evaluation, teacher effectiveness and school effectiveness: Perspectives from the USA. Journal of Professional Evaluation in Education, 17(1), 101-128. http://dx.doi.org/10.1023/A:1025083214622

Gadzella, B. M. (1977, April 17). A comparison of students' perception of an ideal professor. Paper presented at Southwestern Psychological Association Convention, Austin, Texas.

Ghanizadeh, A. (2011). An investigation into the relationship between self-regulation and critical thinking among Iranian EFL teachers. The Journal of Technology of Education, 5 (3), 213-221.

Ghanizadeh, A., \& Moafian, F. (2010). The role of EFL teachers' emotional intelligence in their success. ELT Journal 64 (4), 424-435. http://dx.doi.org/10.1093/elt/ccp084

Ghanizadeh, A., \& Moafian, F. (2011). The relationship between Iranian EFL teachers' sense of self-efficacy and their pedagogical success in Language Institutes. Asian EFL Journal, 13 (2), 249-272.

Ghonsooli, B., \& Ghanizadeh, A. (in press). Self-efficacy and self-regulation and their relationship among Iranian EFL teachers. Language Learning Journal.

Goleman, D. (1995). Emotional Intelligence: Why It Can Matter More Than IQ. New York: Bantam Books.

Hiebert, J., Morris, A.K. Berk, D \& Jansen, A. (2007).Preparing teachers to learn from teaching. Journal of Special Education, 36, 186-205.

Hoffman, B., \& Spatariu, A. (2008). The influence of self-efficacy and metacognitive prompting on math problem-solving efficiency. Contemporary Educational Psychology 33, 875-893. http://dx.doi.org/10.1016/j.cedpsych.2007.07.002

Hsieh, P., Sullivan. J.R. \& Guerra, N. S. (2007). A closer look at college students: Self-efficacy and goal orientation. Journal of Advanced Academics 18(3), 454-476.

Kitsantas, A. (2000). The role of self-regulation strategies and self-efficacy perceptions in successful weight loss maintenance. Psychology and Health 15, 811-820. http://dx.doi.org/10.1080/08870440008405583

Kyriakides, L., Campbell, R. J., \& Christofidou, E. (2002). Generating criteria for measuring teacher effectiveness through a self-evaluation approach: A complementary way of measuring teacher effectiveness. School Effectiveness and School Improvement, 13(3), 291-325. 
Linn, M.C. (2000). Designing the knowledge integration environment. International Journal of Science Education, 22(8), 781-796. http://dx.doi.org/10.1080/095006900412275

Mayer, J.D., \& Salovey, P. (1997). What is emotional intelligence? in P. Salovey and D. J. Sluyter (eds.). Emotional Development and Emotional Intelligence: Implications for Educators. New York: Basic Books.

Moafian, F., \& Pishghadam, R. (2009). Construct validation of a questionnaire on characteristics of successful EFL teachers. Pazhuhesh-e Zabanha-ye Khareji, 53.

Paris, S.G., \& Winograd, P. (2001). The role of self-regulated learning in contextual teaching: Principles and practices for teacher preparation. http://www.ciera.org/library/archive/2001-04/0104parwin.htm

Pintrich, P.R. (1999). The role of motivation in promoting and sustaining self-regulated learning. International Journal of Educational Research 31, 459-470. http://dx.doi.org/10.1016/S0883-0355(99)00015-4

Pintrich, P.R., \& De Groot E. (1990). Motivational and self-regulated learning components of classroom academic performance. Journal of Educational Psychology, 82(1), 33-50. http://dx.doi.org/10.1037/0022-0663.82.1.33

Randi, J. (2004). Teachers as self-regulated learners. Teachers' College Record, 106(9), 1825-1853. http://dx.doi.org/10.1111/j.1467-9620.2004.00407.x

Riachards, J.C., \& Renandya, W.A. (2002). Methodology in Language teaching: an anthology of current practice. Cambridge: Cambridge University Press. http://dx.doi.org/10.1017/CBO9780511667190

Schraw, G., Crippen, K.J., \& Hartley, K. (2006). Promoting self-regulation in science education: Metacognition as part of a broader perspective on learning. Research in Science Education 36, 111-139. http://dx.doi.org/10.1007/s11165-005-3917-8

Suwandee, A. (1995). Students' perceptions of university instructors' effective teaching characteristics. SLLT Journal, 5, 6-22.

Weimer, M. (2002). Learner-centered teaching. San Francisco: Jossey-Bass.

Wheeler, J.V., \& Mcleod, P.L. (2002). Expanding our teaching effectiveness: understanding our responses to "in-the-moment" classroom events. Journal of Management Education, 26, 693-716. http://dx.doi.org/10.1177/1052562902238325

Wubbels, T., \& J. Levy. (1991). A comparison of interpersonal behavior of Dutch and American teachers. International Journal of Intercultural Relations 15, 1-18. http://dx.doi.org/10.1016/0147-1767(91)90070-W

Yesim, C.A., Sungur, S., \& Uzuntiryaki, E. (2009). Teacher self-regulation: examining a multidimensional construct. Educational Psychology 29(3), 345-356. http://dx.doi.org/10.1080/01443410902927825

Zimmerman, B.J. (1990). Self-regulated learning and academic achievement: an overview. Educational Psychologist 25 (1), 3-17. http://dx.doi.org/10.1207/s15326985ep2501_2

Zimmerman, B.J. (1998). Academic studying and the development of personal skill: A self-regulatory perspective. Educational Psychologist 33, 73-86. http://dx.doi.org/10.1207/s15326985ep3302\&3_3

Zimmerman, B.J. (2000). Attaining self-regulation: A social cognitive perspective. In M. Boekaerts, P.R. Pintrich, \& M. Zeidner (Eds.), Handbook of self-regulation (pp. 13-39). San Diego, CA: Academic Press.

Zimmerman, B.J., \& Martinez-Pons, M. (1986). Development of a structured interview for assessing student use of self-regulated learning strategies. American Educational Research Journal, 23, 614-628.

Zimmerman, B.J., \& Risemberg, R. (1997). Self-regulatory dimensions of academic learning and motivation. In G.D. Phye (Ed.): Handbook of academic learning (pp. 105-125). New York: Academic Press. http://dx.doi.org/10.1016/B978-012554255-5/50005-3

Zimmerman, B.J., \& Schunk, D. (2001). Reflections on theories of self-regulated learning and academic achievement. In B. Zimmerman and D. Schunk (Eds.), Self-Regulated Learning and Academic Achievement: Theoretical Perspectives (2nd Ed.) (pp. 289-307). Mahwah, NJ: Erlbaum. 
Table 1. Nine factors of TSRS along with the corresponding descriptions

\begin{tabular}{|l|l|}
\hline \multicolumn{1}{|c|}{ Factor } & \multicolumn{1}{c|}{ Description } \\
\hline 1. Goal setting & Process of establishing objectives to guide actions during instruction \\
\hline 2. Intrinsic interest & Beliefs concerning personal interest in the profession \\
\hline $\begin{array}{l}\text { 3. Performance } \\
\text { goal orientation }\end{array}$ & $\begin{array}{l}\text { Goals to do better than others as a teacher and to have others } \\
\text { believe in one's competence }\end{array}$ \\
\hline $\begin{array}{l}\text { 4. Mastery goal } \\
\text { orientation }\end{array}$ & $\begin{array}{l}\text { Goals to improve competence in teaching and master the teaching } \\
\text { task against self-set standards }\end{array}$ \\
\hline $\begin{array}{l}\text { 5. Self-instruction } \\
\text { control }\end{array}$ & $\begin{array}{l}\text { Process of monitoring one's own performance in teaching and } \\
\text { making instructional changes when necessary }\end{array}$ \\
\hline 7. Self-evaluation & $\begin{array}{l}\text { Strategies for controlling and regulating affect, mood, and } \\
\text { emotions }\end{array}$ \\
\hline 8. Self-reaction & Affective responses following a teaching performance \\
\hline 9. Help-seeking & $\begin{array}{l}\text { Getting help from others to resolve problems encountered in } \\
\text { teaching process }\end{array}$ \\
\hline
\end{tabular}

Table 2. Descriptive statistics of TSRS and CSIET

\begin{tabular}{|l|c|c|c|c|c|}
\hline & $\mathbf{N}$ & Minimum & Maximum & Mean & Std.Deviation \\
\hline TSRS & 76 & 120 & 240 & 178 & 24.5 \\
\hline CSIET & 76 & 123 & 230 & 168 & 25.2 \\
\hline
\end{tabular}

Table 3. The results of correlation between teachers' self-regulation and their success

\begin{tabular}{|c|c|}
\hline & Total self-regulation \\
\hline Success & $0.52 *$ \\
\hline
\end{tabular}

Table 4. The results of correlation between subscales of teachers' self-regulation and their success

\begin{tabular}{|l|c|}
\hline & Teacher Success \\
\hline F1 (Goal setting) & 0.273 \\
\hline F2 (Intrinsic interest) & $0.504^{*}$ \\
\hline F3 (Performance goal orientation) & $0.415^{*}$ \\
\hline F4 (Mastery goal orientation) & $0.430^{*}$ \\
\hline F5 (Self-instruction) & 0.268 \\
\hline F6 (Emotional control) & $0.473^{*}$ \\
\hline F7 (Self-evaluation) & $0.342^{*}$ \\
\hline F8 (Self-reaction) & $0.388^{*}$ \\
\hline F9 (Help-seeking) & $0.317^{*}$ \\
\hline
\end{tabular}


Table 5. The ANOVA table of regression

\begin{tabular}{|c|l|c|c|c|c|c|}
\hline \multicolumn{2}{|l|}{ Model } & Sum of Squares & df & Mean Square & F & Sig. \\
\hline \multirow{2}{*}{1} & Regression & 15514.080 & 9 & 1723.787 & 3.510 & $.001^{\mathrm{a}}$ \\
\cline { 2 - 7 } & Residual & 32408.802 & 66 & 491.042 & & \\
\cline { 2 - 7 } & Total & 47922.882 & 75 & & & \\
\hline
\end{tabular}

Predictors: (Constant), Goal setting, Intrinsic interest, Performance goal orientation, Mastery goal orientation, Self-instruction, Emotional control, Self-evaluation, Self-reaction, Help-seeking.

Dependent Variable: Teacher success

Table 6: The results of regression analysis for the components of teachers' Self-regulation and Success

\begin{tabular}{|c|c|c|c|c|c|c|}
\hline \multicolumn{7}{|c|}{ Coefficients $^{\mathrm{a}}$} \\
\hline \multirow{2}{*}{\multicolumn{2}{|c|}{ Model }} & \multicolumn{2}{|c|}{$\begin{array}{l}\text { Unstandardized } \\
\text { Coefficients }\end{array}$} & \multirow{3}{*}{$\begin{array}{c}\begin{array}{c}\text { Standardized } \\
\text { Coefficients }\end{array} \\
\text { Beta }\end{array}$} & \multirow{3}{*}{$\begin{array}{c}\mathbf{t} \\
3.828\end{array}$} & \multirow{3}{*}{$\begin{array}{l}\text { Sig. } \\
.000\end{array}$} \\
\hline & & \multirow{2}{*}{$\begin{array}{c}\text { B } \\
84.183\end{array}$} & \multirow{2}{*}{$\begin{array}{c}\text { Std. Error } \\
21.990\end{array}$} & & & \\
\hline 1 & (Constant) & & & & & \\
\hline & Goal setting & -.320 & .770 & -.052 & -.415 & .679 \\
\hline & Intrinsic interest & 2.345 & 1.244 & .327 & 2.085 & .046 \\
\hline & Performance goal orientation & 1.075 & 1.382 & .122 & .778 & .439 \\
\hline & Mastery goal orientation & 1.041 & .998 & .167 & 1.043 & .301 \\
\hline & Self-instruction & -.345 & .784 & -.060 & -.440 & .661 \\
\hline & Emotional control & 1.129 & .826 & .224 & 1.367 & .176 \\
\hline & Self-evaluation & -.348 & 1.283 & -.041 & -.272 & .787 \\
\hline & Self-reaction & -1.333 & 1.465 & -.164 & -.910 & .366 \\
\hline & Help-seeking & 1.075 & 1.167 & .121 & .921 & .360 \\
\hline & endent Variable: Success & & & & & \\
\hline
\end{tabular}

Table 7: The results of regression analysis for teachers' Self-regulation and Success

\begin{tabular}{|c|c|c|c|c|c|c|}
\hline & \multirow{2}{*}{ Model } & \multicolumn{2}{|c|}{ Unstandardized Coefficients } & \multirow{2}{*}{$\begin{array}{c}\begin{array}{c}\text { Standardized } \\
\text { Coefficients }\end{array} \\
\text { Beta }\end{array}$} & \multirow[t]{2}{*}{$\mathbf{t}$} & \multirow[t]{2}{*}{ Sig. } \\
\hline & & B & Std. Error & & & \\
\hline \multirow[t]{2}{*}{1} & (Constant) & 71.499 & 18.337 & & 3.899 & .000 \\
\hline & $\begin{array}{l}\text { Self- } \\
\text { regulation }\end{array}$ & .544 & .102 & .527 & 5.341 & .000 \\
\hline
\end{tabular}

Table 8: R square table for teachers' self-regulation as the predictor of their success

\begin{tabular}{|c|c|c|c|c|}
\hline Model & R & R Square & Adjusted R Square & Std. Error of the Estimate \\
\hline 1 & $.527^{\mathrm{a}}$ & .278 & .268 & 21.61980 \\
\hline
\end{tabular}

